\title{
Late-stage melanoma presenting with cannonball metastases
}

\author{
Ashima Lowe, Jonathan James Hyett Bray
}

Acute Medical Admissions Unit, Morriston Hospital, Swansea, UK

\section{Correspondence to}

Dr Jonathan James Hyett Bray; jonathan.bray@doctors.org.uk

Accepted 3 November 2020

\section{DESCRIPTION}

A 68-year-old previously fit and well American man presented generally unwell to the medical admissions unit. He gave a 6-month history of weight loss and loss of appetite but no specific systemic symptoms. He had not needed to attend his general practitioner in the previous 23 years of living in the UK. He was noted to be markedly cachectic on admission and a chest radiograph demonstrated prominent cannonball metastases (figure 1). He went on to have a CT of the thorax, abdomen and pelvis which confirmed the pulmonary metastases seen on the chest radiograph, and additionally showed splenic deposits, left axillary and hilar lymphadenopathy, but no primary was identified. He was subsequently referred to the multidisciplinary team meeting of unknown primary for further investigation.

As a redeployed dermatologist due to the COVID-19 pandemic, I walked past his bed and noticed that he was deeply tanned. A full skin examination seemed warranted. Examination of the back revealed three large plasters, under which three suspicious lesions were identified. The largest was a $6 \times 4 \mathrm{~cm}$ diameter fungating, skin-coloured, ulcerated plaque on the left upper back, just medial to the scapula (figure 2). Of note, there were illdefined mid-dark brown areas (see arrows) suggestive of a pigment network. In addition, there were two $2 \times 1.5 \mathrm{~cm}$ ulcers with a raised edge on the left lower back and right shoulder. On specific questioning, he described the largest lesion starting as a small brown mark that grew rapidly to its present

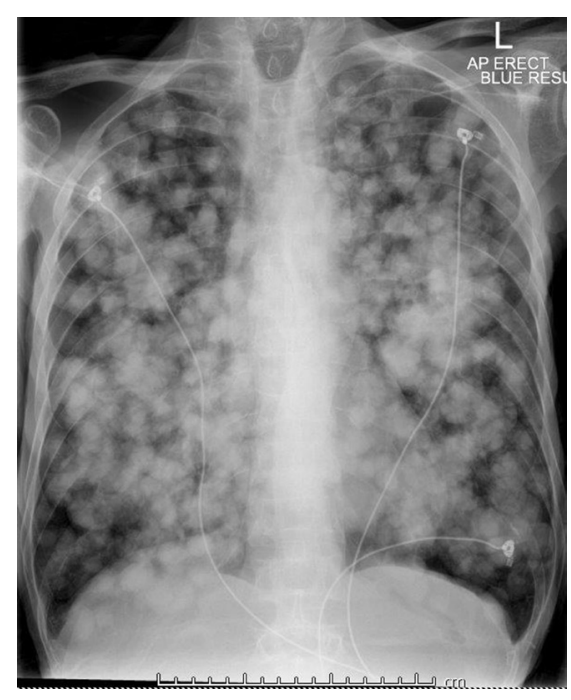

Figure 1 Chest radiography demonstrating multiple rounded airspace opacities consistent with 'cannonball metastases'.

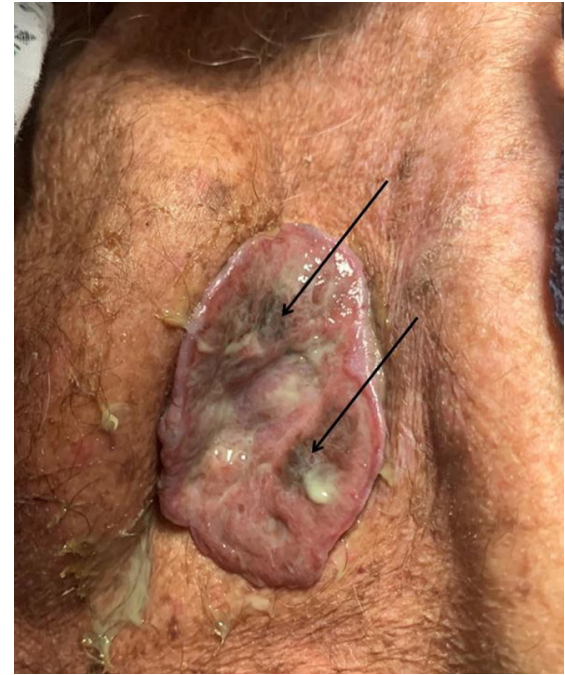

Figure 2 Fungating erythematous $6 \times 4 \mathrm{~cm}$ plaque with irregular foci of mid-dark brown pigmentation, medial to the left scapula.

size over approximately 1 year. It was extremely uncomfortable and he was keen to have it removed, despite declining all other medical therapy. $\mathrm{He}$ admitted he was an avid sun worshipper and had never used any sun protection all his life.

The lesions were excised and a biopsy taken from the most accessible lymph node in the left axilla. Histology confirmed that the largest lesion (left upper back, figure 2) was a nodular malignant melanoma, Breslow thickness $10 \mathrm{~mm}$, with microsatellites. Metastatic melanoma was identified in the left axillary lymph node. Therefore, we can assume that the patient's widespread metastases arose from the cutaneous malignant melanoma excised from the left upper back, which was the likely primary focus. The two smaller ulcerated skin lesions were confirmed histologically to be infiltrative basal cell carcinomas and were unrelated to his current presentation but also reflect his degree of sun exposure. The patient may have been a candidate for immunotherapy for his metastatic melanoma, but sadly he died a few days after biopsies were taken.

The lung and pleura are the most common sites of visceral metastases from melanoma ${ }^{1}$ and autopsy series of patients with late-stage melanoma show lung metastases in $>85 \%$ of patients. ${ }^{2}$ Cannonball metastases are commonly associated with betahuman chorionic gonadotropin-secreting tumours, ${ }^{3}$ but rarely seen in the context of malignant melanoma. There are only three previous reports of melanoma presenting with cannonball metastases, all of which describe a challenge in identifying the 


\section{Learning points}

- The skin is the largest and most visible organ, easily lending itself to examination and must not be forgotten in patients presenting with metastatic cancer of unknown primary.

- Malignant melanoma can uncommonly present with cannonball metastases.

- Late-stage melanomas can unusually present as fungating tumours, with only minimal pigment network that can provide a clue to the diagnosis.

primary source. ${ }^{4-6}$ One report describes a history of melanoma removal $^{4}$ and another only non-pigmented nodules as clues to the malignant origin. ${ }^{5}$

Contributors AL was responsible for discovering the case, jointly conceptualising the case report, writing the first manuscript and obtaining the images. JJHB was responsible for jointly conceptualising the case report, reviewing the literature, obtaining consent and editing the final manuscript. Both authors edited and reviewed the manuscript, and have approved the final version.
Funding The authors have not declared a specific grant for this research from any funding agency in the public, commercial or not-for-profit sectors.

Competing interests None declared.

Patient consent for publication Obtained.

Provenance and peer review Not commissioned; externally peer reviewed.

\section{ORCID iD}

Jonathan James Hyett Bray http://orcid.org/0000-0003-1167-6295

\section{REFERENCES}

1 Damsky WE, Rosenbaum LE, Bosenberg M. Decoding melanoma metastasis. Cancers 2011;3:126-63

2 Balch CM, Houghton AN, Sober AJ, et al. Cutaneous melanoma. 4th ed. St Louis, MO, USA: Quality Medical Publishing, 2003.

3 Yang R-H, Ting C-H, Chu Y-K. Cannonball lung metastases as a presenting feature of ectopic hCG expression. Journal of Oncological Sciences 2016;2:58-62.

4 Newsom RS, Simcock P, Zambarakji H. Cerebral metastasis presenting with altitudinal field defect. J Neuroophthalmol 1999;19:10-11.

5 Ghosh SK, Bandyopadhyay D, Barma KD, et al. Metastatic melanoma from an unknown primary site presenting as skin-colored nodules and multiple visceral involvement. Skinmed 2012;10:396-9.

6 Namdeo A, Kumar S, Jain M, et al. Malignant melanoma metastasizing to the stomach: two cases of a rare disease with different presentation in Gi tract. Indian J Gastroenterol 2010;29:A111-2.

Copyright 2020 BMJ Publishing Group. All rights reserved. For permission to reuse any of this content visit

https://www.bmj.com/company/products-services/rights-and-licensing/permissions/

BMJ Case Report Fellows may re-use this article for personal use and teaching without any further permission.

Become a Fellow of BMJ Case Reports today and you can:

- Submit as many cases as you like

- Enjoy fast sympathetic peer review and rapid publication of accepted articles

- Access all the published articles

Re-use any of the published material for personal use and teaching without further permission

\section{Customer Service}

If you have any further queries about your subscription, please contact our customer services team on +44 (0) 2071111105 or via email at support@bmj.com.

Visit casereports.bmj.com for more articles like this and to become a Fellow 